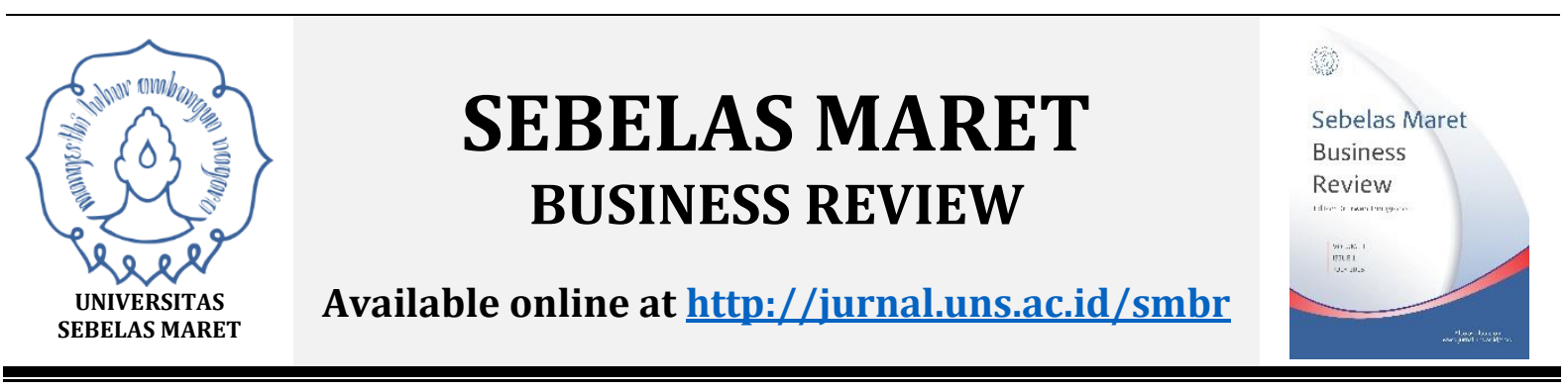

\title{
ANTECEDENTS OF ONLINE REPURCHASE INTENTION IN INDONESIA
}

\author{
Ignatius Hari Santoso \\ Stikubank University, Semarang \\ Corresponding author: ignatiusnutriyo@gmail.com
}

\begin{abstract}
ARTICLE INFO
ABSTRACT

Article History:

Online buying activity is increased along with the increased

Received 18 January of internet-based information technology. This gives 2018

Accepted 21 February 2018

Available online 22

February 2018 benefit to online businessman and businesswoman. However, the efforts which should be given are harder than before because of the increasing of online criminality which happened in Indonesia. The objective of this study generally is to reveal the antecedents of online repurchase intention in Indonesia. This study is using 170 respondents who have experience in online purchasing at least one

Keywords: times before. Visual Partial Least Square is used to examine the relationship between constructs. This study concludes

Stimulus Organism Response Theory, that the developed model which used in this study can be used to predict online repurchase intention even several Online Repurchase Intention, Online relationships is found not significant. Another conclusion from this study is perceived information quality, perceived Satisfaction, Online Trust service quality, subjective norms, online shopper's trust, and online shoppers' satisfaction are the antecedents of online repurchase intention.
\end{abstract}

\section{INTRODUCTION}

\section{Research Background and Purpose}

This research is focused on online repurchase intention which is crucial for the businessman. When the initial attempt to stand, businessman, will try to out loud how to 
make customer interested to do online purchasing. A variety of effort has been carried out by the owner.

Efforts to defending consumers become more severe due to the common fraud cases when purchasing products online through a social networking site. This is an interesting issue because in general, people tend to reduce the online purchase activities if the public knew the high risk to be faced. However, the phenomenon happening in Indonesia shows that even though peoples aware of many fraud cases in online commerce, the propensity to buy products online is increased from the previous year. According to this phenomenon which described above, researcher proposed research question: "What are the antecedents of online repurchase intention?" This research is aimed to explain the effect of perceived system quality, perceived information quality, perceived service quality, subjective norm, perceived price, online shopper's satisfaction toward online repurchase intention.

Theoretically, this research supports the enrichment of management information system literature, especially which related to online repurchase intention by using Stimulus - Organism - Response theory. There is so many research by using Technology Acceptance Model (Ahn et al., 2007; Al - Maghrabi et al., 2010), Theory of Planned Behavior (Corbitt et al., 2003; Pavlou and Gefen, 2004). By this research, people can more aware that online repurchase intention can be explained by using Stimulus - Organism Response Theory.

Practically, this research provides information to an online businessman the important of perceived information quality, perceived system quality, perceived service quality, perceived price, subjective norms, shopper's trust and satisfaction in conducting an online transaction. By concerning the constructs, the businessman is expected to easier to retain their customer.

\section{Hypotheses Development Information System Success Model}

Information System Success Model was first proposed by DeLone and McLean in 1992. This Model suggests that individual attitude and his behavior is determined by the individual belief itself of the quality of information and systems. According to DeLone and McLean (2003) system quality construct measured success of the technical aspects of the information system. Further Kuan et al. (2008) expressed that system quality is characteristic of a system of e-commerce in the form of ease of use, consistency, attractiveness, speed to log out, and the time which required to downloading.

DeLone and McLean (2003) next argued that the accuracy, up to date, completeness, relevance; and consistency have been used to measure the quality of information of a website. Besides perceived information quality defined as a level which the user sure that information on the website is precise information (Rai et al., 2002).

About service quality, Palmer (2002) defined it as tiers where users believe that website the responsive and interactive. Besides, Vassilopoulou et al. in Kuan et al. (2008) explained that in addition to responsive and interactive, the website also must have a clear policy on security and privacy and having a facility for finding items.

\section{Theory of Reasoned Action}

The second theory that became a cornerstone of this research is the Theory of Reasoned Action. This theory was proposed by Ajzen and Fishbein in 1980 to predict individual behavior. According to Hartono (2007) Theory of Reasoned Action assumed that the man usually behaves in a manner that is mindful, consider the information 
available, and also consider the implications of actions which have been taken. Individual behavior is influenced directly by individual intention to behave. Whereas the intention to behave influenced by attitudes towards behavior and subjective norms.

According to Ajzen (1991), subjective norms are perceptions of the individual to do or not to do a behavior. Furthermore, Bhatacherjee in Hsu and Chiu (2004) revealed that subjective norm consisting of two essential part, namely the influence of interpersonal and external influences. The influence of interpersonal is the influence of friends, a member of the family, your colleagues, coworkers, superiors, and individuals, while external influences is the influence of outside parties that from the media, information and opinions of experts, and other personal information in doing his behavior (Bhatacherjee in Wijayanti, 2012).

\section{Stimulus - Organism - Response Theory}

Then the Theory of Stimulus - Organism - Response developed by Mehrabian and Russell in 1974 as the third base theory in this research. This theory has the assumption that environmental influences (stimulus) affect the individual organism emotional (organism) that could eventually affect the behavior (response) (Hsu and Tsou, 2011).

By using this theory, researchers positioning independent variables in this research as stimulants, online shoppers' trust and online shoppers' satisfaction as a form of emotion and online repurchase intention as a response from the user. Also, this theory could also be used to explain the role of perceived price. The price can be said reasonably if the benefits which perceived by individuals beyond perceived sacrifice (Hermann et al., 2007).

\section{Technology Acceptance Model}

Technology Acceptance Model developed by Davis in 1989. Constructs which have been used are usability, ease of use, attitude toward the behavior, intention to behave, and behavior. Taylor and Todd in Hartono (2007) defined facilitating condition as control beliefs related to the resource factors such as time, money, and the compatibility of information technology which may be able to inhibit the use of technology. Based on this definition, researchers use a modified Technology Acceptance Model (in particular the addition of external variables) to explain the influence of price against the online repurchase intention.

\section{The Relationship between Perceived System Quality toward Online Repurchase Intention, Online Shoppers' Satisfaction, and Online Shoppers' Trust}

Kuan et al. (2008), Chen and Cheng (2009), and Zhang et al, (2011) proved that the perceived quality of the web have significant effects and positive toward online repurchase intention. Based on several studies, the researchers propose hypotheses as follows.

H1a: The perceived system quality is positively associated with online repurchase intention.

The quality system also has a positive and significant effect toward online shoppers' satisfaction as has been evidenced by Chen and Cheng (2009), McGill and Klobas (2008), Liao et al., (2011) and Lin et al. (2011). According to several studies before, then researcher propose the hypotheses as follows.

H1b: The perceived system quality is positively associated with online shoppers' satisfaction. 
Perceived system quality also has a significant and positive influence toward online shoppers' trust as evidenced by Hwang and Kim (2007), Zhou (2012). According to several studies before, then researcher propose the hypotheses as follows.

H1c: The perceived system quality is positively associated with online shoppers' trust.

\section{Relationship Between Perceived Information Quality toward Online Repurchase Intention, Online Shoppers' Satisfaction and Online Shoppers' Trust.}

Nicolaou and McKnight (2006), Almahamid et al, (2005), (Kuan et al. (2008) and, Chen and Cheng, (2009) have proved that information quality affects directly, significant and positive toward online repurchase intention. According to several studies before, then researcher propose the hypotheses as follows.

H2a: The perceived information quality is positively associated with online repurchase intention.

Perceived information quality also influences online shoppers' satisfaction. This is evidenced by Chen and Cheng (2009), Hsieh et al. (2010), Park et al. (2010), Liao et al. (2011) and Gao, J. et al. (2012). According to several studies before, then researcher propose the hypotheses as follows.

H2b: The perceived information quality is positively associated with online shoppers' satisfaction.

Perceived information quality also has an impact on consumer trust as shown by Chen et al, (2011), Kim et al. (2011), Bock et al, (2012), Zhou (2012) and Lee and Chung (2009). According to several studies before, then researcher propose the hypotheses as follows.

H2c: The perceived information quality is positively associated with online shoppers' trust.

\section{Relationship Between Perceived Service Quality toward Online Repurchase Intention, Online Shoppers' Satisfaction, and Online Shoppers' Trust}

Another researcher who have used service quality is Kuan et al. (2008); Chen and Cheng, (2009), Kuo et al. (2009), and Gera (2011). They have proved that there was a significant influence and positive between perceived service quality toward online repurchase intention. According to several studies before, then researcher propose the hypotheses as follows.

H3a: The perceived service quality is positively associated with online repurchase intention.

Chen and Cheng (2009), Liao et al. (2011), Kettinger et al. (2009), Yang et al. (2009) have proved that perceived service quality significant and positively influenced online shoppers' satisfaction. Thus researcher propose a hypothesis as follows

H3b: The perceived service quality is positively associated with online shoppers' satisfaction.

Besides Mao (2010), Kim et al. (2011), Halimi et al. (2011), Ghane et al. (2011) and Zhou (2012) prove that the higher quality of service then the higher mobile banking 
application user's trust. According to several studies before, then researcher propose the hypotheses as follows.

H3c: The perceived service quality is positively associated with online shoppers' trust.

\section{Relationship Between Subjective Norms toward Online Repurchase Intention, Online Shopper's Satisfaction, and Online Shoppers' Trust}

Lee et al. (2007), Liao et al. (2007), Ramayah et al. (2009), Al-Maghrabi et al. (2010) and Yulihasri et al. (2011) proved that subjective norms influenced online repurchase intention. According to several studies before, then researcher propose the hypotheses as follows.

H4a: The subjective norms is positively associated with the online repurchase intention.

Subjective norms also have influence toward user's satisfaction as evidenced by Roca et al. (2006), Chen et al. (2012) which have proven that subjective norms have significant and positive influence toward web 2.0 application user satisfaction.

However, the research which has been conducted by Bhatacherjee in Hsu and Chiu (2004) demonstrated that only interpersonal influence (decomposition of subjective norms) proved influential significantly and favorably to satisfaction, while the external influences (decomposition from subjective norms) had no influenced significantly to satisfaction. According to the Stimulus - Organism - Response Theory, researcher propose a hypothesis as follows

H4b: The subjective norms is positively associated with the higher online shoppers satisfaction.

Also, subjective norms also had a significant and positive impact on online shoppers' trust as shown by Hitosugi (2011), Jeffries and Becker (2008), Currall and Judge (1992), and Li et al. (2008). According to several studies before, the researcher proposes a hypothesis as follows.

H4c: The subjective norms is positively associated with online shoppers trust.

\section{Relationship Between Perceived Price toward Online Repurchase Intention, Online Shoppers' Satisfaction, and Online Shoppers' Trust.}

Also, Bolton and Lemon in Jiang and Rosenbloom (2005), Lodorfos et al. (2006), Liao et al. (2008), Kim et al. (2011) have shown that the more reasonable (fair) price, the greater an individual intention to buy back the product. Based on some research results above, the researcher proposes the following hypothesis

H5a: The perceived price is positively associated with online repurchase intention.

Jiang and Rosenbloom (2005), Voss et al. and Fornell in Jiang and Rosenbloom (2005), Ali et al. (2010), Hanif et al. (2010), Munusamy et al. (2011) proved that the perceived fairness price had a significant and positive impact on satisfaction. Based on some research results, the researcher proposes the following hypothesis.

$\mathrm{H} 5 \mathrm{~b}$ : The perceived price is positively associated with online shoppers satisfaction.

Beside Anuwichanont (2011), Grewal et al. (2004), Zhang and Feng (2009) revealed that the more reasonable the price of the product the higher consumers' trust. Based on the several past researches, the researchers propose hypotheses as follows. 
H5c: The perceived price is positively associated online shoppers trust.

\section{Relationship Between Online Shoppers' Trust toward Online Repurchase Intention}

Pavlou and Gefen (2004), Wang et al. (2009), Ou and Sia (2010), Chiu et al. (2010). They have proved the existence of a significant and positive influence of trust to online repurchase intention. Thus, based on some results of previous research and Relationship Marketing Perspective researcher proposes hypotheses as follows.

H6: The online shoppers' trust is positively associated online repurchase intention.

\section{Relationship Between Online Shopper's Satisfaction toward Online Repurchase Intention}

Besides, Zeng et al. (2009), Chen and Cheng (2009), Lin et al. (2010), Chen et al. (2010), Liao et al. (2011) have proved that consumer satisfaction is a significant and positive effect online repurchase intention. Based on the studies result before, the researcher proposes hypotheses as follows.

H7: The online shoppers' satisfaction is positively associated with the online repurchase intention.

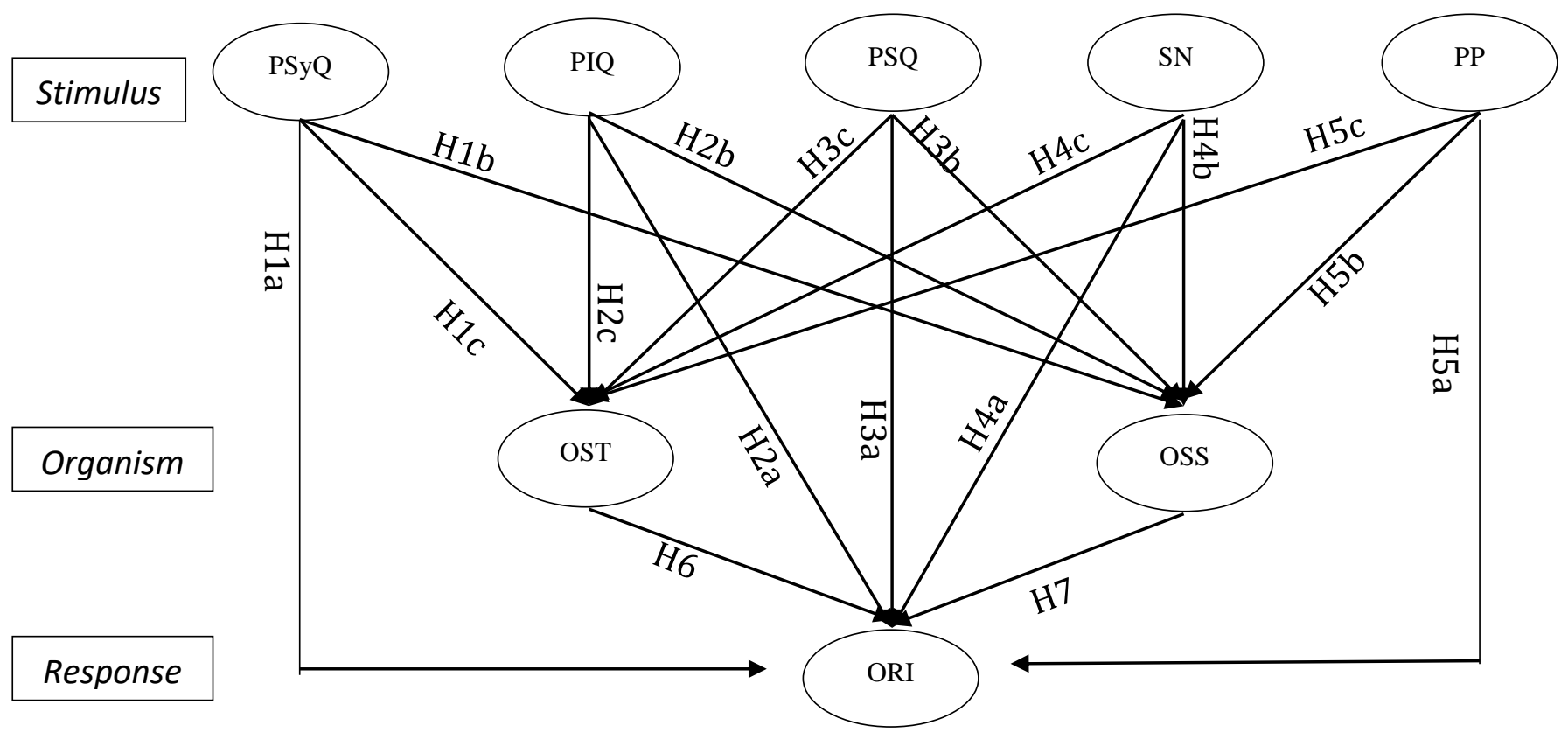

Figure 2.1. Research Model

Sources: Liao et al. (2011), Al - Maghrabi et al. (2010), Kuan et al. (2008), Liao et al. (2008), Jiang and Rosenbloom (2005), and Hsu and Chiu (2004).

Notes:

PSyQ : Perceived System Quality.

PP : Perceived Price.

PIQ : Perceived Information Quality.

OST : Online Shopper's Trust.

PSQ : Perceived Service Quality.

OSS : Online Shopper's Satisfaction.

SN : Subjective Norms.

ORI : Online Repurchase Intention. 


\section{RESEARCH METHOD}

\section{Research Samples}

Respondent selection technique which used in this study is Snowball technique. According to Neuman (2000), Snowball sampling was a sampling method based on a network. In accordance with the analogy of a snowball, which began with a small size, and long-run size will be even bigger.

The number of respondents which used in this study were 170 respondents. The amount is in accordance with the minimum requirement number of respondents using the PLS-SEM. It is ten respondents for each lane (Hartono and Abdillah, 2009). While the criteria used in the study respondents are internet users, who have experience of minimum one-time purchase products by online.

\section{Data Collection Techniques}

Data collection techniques which used in this study is a survey technique using a questionnaire that was sent via E-mail because of cost, capable of reaching respondents in a short time, and could exceed the geographical limitation.

\section{Variable Definition}

This study operationalizes Perceived Quality System based on research conducted by Ahn et al. (2007) which defines the quality system as the performance characteristics of a web site which oriented to the technical aspects.

This study operationalizes Perceived Quality of information based on research conducted by Ahn et al. (2007) which defined the quality of information as the performance characteristics of web sites oriented to the technical and operational aspects.

This study operationalizes Perceived Quality of information based on research conducted by Ahn et al. (2007) which defined service quality as the availability of communication mechanisms to receive complaints filed by customers and provide responsive solutions, advanced services, and provision of guarantees.

This research operationalizes Subjective Norms based on research conducted by Ajzen (1991), namely the perceived social pressure to perform or not perform a behavior. Furthermore, Bhatacherjee in Hsu and Chiu (2004) looked at the norm in two forms, namely subjective interpersonal influence and external influence. Thus in this research, Subjective Norms is measured based on the dimensions of interpersonal influence and external influence.

According to Chu and $\mathrm{Lu}$ (2007) price of the product is often used as a tool to measure how much the sacrifices that must be done by the consumer to obtain a product. The price of a product can be said to be fair if the perceived benefits by an individual toward a product or service exceeds the perceived sacrifice by the individual (Hermann et al., 2007). In this research the operational definition of Perceived Price is the extent to which consumers consider that the price to be paid commensurate with the benefits received and measured by the dimensions of compliance with performance pricing, pricing that exceeds customers' expectations, and the suitability of the price paid to the value measured in money.

Researcher operationalizes the construct of Online Shoppers' Trust based on research conducted by Ganguly et al. (2010) that perceptions of credibility and goodness (benevolence) online stores in the eyes of consumers. Credibility can be understood as a belief in the expertise of the buyer by the seller in carrying out the work effectively. While 
the goodness (benevolence) is the buyer's belief that there is a positive intention of the seller (Ganesan in Ganguly et al., 2010).

This study to operationalize the construct Online Shopper's Satisfaction in the opinion of Szymanski and Henard in Tsai and Huang (2007). It was the condition of positive feelings as a result of the evaluation of overall performance based on the experience of purchasing and consumption of the previous product.

Researcher operationalizes Online Repurchase Intention construct as the individual's desire to repurchase products through the same online shopping site.

\section{RESULTS AND DISCUSSION}

\section{General Description}

Table 4.1. General Description

\begin{tabular}{llcc}
\hline & Category & Respondent & Percentage \\
\hline Age & $17-30$ & 127 & $74,71 \%$ \\
& $31-40$ & 43 & $25,29 \%$ \\
Occupation & Total & 170 & $100 \%$ \\
& Private sector & 94 & $55,29 \%$ \\
& Government officer & 3 & $1,77 \%$ \\
& State-owned & & \\
& company & 27 & $15,88 \%$ \\
Product & Non-job & 46 & $27,06 \%$ \\
& Total & 170 & $100 \%$ \\
& Electronic & 50 & $29,41 \%$ \\
& Books & 41 & $24,12 \%$ \\
& Watch & 35 & $20,59 \%$ \\
Sex Type & Daily needs & 21 & $12,35 \%$ \\
& Clothing & 23 & $13,53 \%$ \\
& Total & 170 & $100 \%$ \\
& Male & 78 & $45,88 \%$ \\
& Female & 92 & $54,12 \%$ \\
& Total & 170 & $100 \%$ \\
\hline
\end{tabular}

\section{Measurement Model Evaluation}

The result of convergent validity test showed that there are some indicators which do not have a standardized loading greater than 0.5. It is on PSyQ1, PSyQ8, PIQ2, PSQ4, SN6, PP3, and OST4. For that researcher removes the indicators which not qualified, and conduct second stage validity test.

In the second phase, all indicators are declared as valid because it has a standardized loading more than 0.5 and not going cross loading. To test the reliability of indicators, the researcher uses a composite reliability parameter. Indicators are declared valid if composite reliability value produces more than 0.7 . Reliability test result shown in Table 4.2 . 
Table 4.2. Reliability Test

\begin{tabular}{|c|c|c|c|}
\hline Construct & $\begin{array}{l}\text { Composite } \\
\text { Reliability }\end{array}$ & AVE & Cronbach Alpha \\
\hline PSyQ & 0,855637 & 0,500642 & 0,795233 \\
\hline PIQ & 0,829031 & 0,450506 & 0,754333 \\
\hline PSQ & 0,834833 & 0,505669 & 0,753112 \\
\hline SN & 0,909555 & 0,66939 & 0,875093 \\
\hline PP & 0,868756 & 0,768244 & 0,703104 \\
\hline OST & 0,926528 & 0,678403 & 0,90468 \\
\hline OSS & 0,857695 & 0,602759 & 0,778272 \\
\hline ORI & 0,840375 & 0,569815 & 0,747871 \\
\hline
\end{tabular}

\section{Structural Model Evaluation}

The results of structural model evaluation based on the parameters $\mathrm{T}$ - statistics in this study are shown in Table 4.3.

Table. 4.3. T - Statistic

\begin{tabular}{lcccc}
\hline & $\begin{array}{c}\text { Entire } \\
\text { Sample } \\
\text { Estimate }\end{array}$ & $\begin{array}{l}\text { Mean of } \\
\text { Subsamples }\end{array}$ & $\begin{array}{l}\text { Standard } \\
\text { Error }\end{array}$ & $\begin{array}{l}\text { T- } \\
\text { Statistic }\end{array}$ \\
\hline PsyQ -> OST & 0,408 & 0,4054 & 0,0681 & 59,876 \\
PsyQ -> OSS & 0,37 & 0,3751 & 0,0625 & 59,201 \\
PsyQ -> ORI & $-0,243$ & $-0,2465$ & 0,0578 & $-42,018$ \\
PIQ -> OST & 0,129 & 0,1301 & 0,0656 & 19,671 \\
PIQ -> OSS & 0,011 & 0,0658 & 0,0509 & 0,2163 \\
PIQ -> ORI & 0,317 & 0,3203 & 0,0594 & 53,343 \\
PSQ -> OST & 0,056 & 0,0891 & 0,0633 & 0,8845 \\
PSQ -> OSS & 0,255 & 0,2657 & 0,0561 & 45,481 \\
PSQ -> ORI & 0,117 & 0,1191 & 0,0607 & 19,267 \\
SN -> OST & 0,239 & 0,2255 & 0,0492 & 48,532 \\
SN -> OSS & 0,367 & 0,3555 & 0,0446 & 82,207 \\
SN -> ORI & 0,47 & 0,4752 & 0,0603 & 77,883 \\
PP -> OST & $-0,097$ & $-0,104$ & 0,0484 & $-20,032$ \\
PP -> OSS & 0,048 & 0,0673 & 0,0475 & 1,01 \\
PP -> ORI & 0,187 & 0,1851 & 0,0579 & 32,319 \\
OST - > ORI & 0,202 & 0,2111 & 0,067 & 30,134 \\
OSS -> ORI & 0,226 & 0,2185 & 0,0745 & 30,339 \\
\hline
\end{tabular}

The results of this study indicate that although the online fraud case frequently reported, consumers still intend to buy the product online because colleagues, friends, and family showed a positive impression on an online shopping site. Thus, online businessman/woman must maintain the image and reputation of their online business in front of the consumer, because when consumers disappointed negative sentiment quickly spread to other potential customers.

The second thing that must be of concern to the business is the perceived information quality. When an individual decides to buy back the product through online shopping sites, the availability of accurate, precise, and the latest (up to date) is not to be overlooked. Accurate, precise, reliable, current (up to date), are showing the seriousness of online businessman/woman. 
Buying products through online shopping sites similar to buying products that have not been touched before. To avoid deceptive practices, consumers will pay more attention to the availability of business information such as address, bank account number, product size, the color of products, product weight, shipping, and so forth. The absence of vital information that will reduce the online repurchase intention.

The third thing that should be concerned with increasing the frequency of online purchase is online shopper's satisfaction. If consumers are satisfied, then the consumer will purchase a product through the same online sites. However, although consumers are satisfied, the possibility to switch to other online sites still could happen. This is because the consumer is easy to make comparisons between online sites with each other, so that when consumers find other online sites are more profitable, then the consumer will switch.

The fourth thing to be noticed by online businessman/woman is an online shoppers trust. Accordance with Relationship Marketing Perspective, online businessman/woman, should always maintain the relationships quality with its customers. To keep the business relationship is maintained properly, there needs to be mutual trust between the two sides, especially the trust of the customer.

Business relationships are based on trust between consumers and businessman/woman because of every online transaction prone to acts of fraud. For that online businessman/woman should have a strong commitment to maintaining relationships with customers.

The fifth things that need to be considered by being perceived service quality. Online businessman/woman has to ensure that online consumers get the service as well as offline consumers. Hospitality and alertness of customer service and marketing representatives on the brick and mortar businesses have to be felt by consumers when shopping online. For that reason, online chats need to be provided as the physical presence of the customer service or marketing representatives.

Also, this study also proves that perceived system quality is not influenced toward online repurchase intention. Online shoppers are not affected by an attractive web design, ease of navigation, speed of response, safety in storing customer data and good functionality because basically, the user will buy a product, rather than buying a system so even if the display was very interesting, but the required product is not interesting, then consumers will not buy the product. Despite, the quality of the system can affect consumer trust and satisfaction, so online businessman/woman must consider the system quality from the sites they manage.

Furthermore, this study also shows that there is no significant relationship between perceived information quality and online shoppers' satisfaction. This occurs because consumers who have purchased products through the same website did not see any significant change regarding the provided information quality.

The rise of online fraud cases resulted in higher expectations over the accurate, current and reliable information. However, the high expectations can not be met by the online businessman/woman because the scope of information available on the online shopping site has not changed since the consumer purchase the product in the first time. Despite, the available information still can build online shoppers' trust.

Furthermore, the perceived service quality is also not proven to have a significant effect on online shoppers' trust. It was due to the availability of the communication channel, providing responsive solutions, advanced services, and the provision of collateral is not sufficient to overcome consumer fears increased as a result of the rising online fraud cases. 
The inability of online business owners to overcome the consumer concern because there is no addition of communication channels and providing a better guarantee. Besides, service which perceived by consumers is not as good when compared to the services obtained when purchasing products through the offline store.

This study also shows that the perceived price has no significant effect on online repurchase intention. This occurs because consumers already have high trust to an online shopping site although the price offered has increased.

Besides, the perceived price also does not affect the consumer satisfaction because consumers see that the price has been offered compared with other online shopping sites are not too much different, then it is not meet the customer's expectation. However, it does not mean the price factor can be avoided by online businessman/woman.

The results of this study are interesting because generally price become into consumer's consideration before making a transaction. However, it does not mean the business online can ignore the price factor. Online businessman/woman should consider the pricing strategies which adopted because perceptions of price can affect online shoppers' trust.

\section{CONCLUSION}

\section{Implications}

The model in this research can be used and developed by another researcher to predict the online repurchase intention even several constructs is proved not supported. Thus, perceived information quality, perceived service quality, subjective norms, online shopper's trust, and online shopper's satisfaction are the antecedents of online repurchase intention.

\section{Limitations}

Although the model in this study can be used in predicting online repurchase intention, the study still has some limitations below.

1. This research uses respondents who had experience of shopping through online shopping sites, not an online portal.

2. Related to the sampling method used is Snowball, the researcher found that by using such a method the sample which used less representing the population.

3. Data collection technique which used in this study is using a questionnaire that sent via e-mail, which still has the possibility that ineligible people fill the questionnaires.

\section{REFERENCES}

Al - Maghrabi, T., Dennis, C. and Halliday, S.V. (2010), "Adapting TAM and ECT: Continuance Intention of E-Shopping in Saudi Arabia", European and Mediterranean Conference on Information System, pp. 1-17.

Ahn, T., Ryu, S. and Han, I. (2007), "The Impact of Web Quality and Playfulness User Acceptance of Online Retailing", Information and Management, Vol. 44, pp. 263-275. Ajzen, I. (1991), "The Theory of Planned Behavior", Organizational Behavior and Human Decision Process, Vol. 50, pp. 179-211.

Ali, J.F., Ali, I., Rehman, K., Yilmaz, A.K., Safwan, N. and Afzal, H. (2010), “Determinants of 
Consumer Retention in Cellular Industry of Pakistan", African Journal of Business Management, Vol. 4 No. 12, pp. 2402-2408.

Almahamid, S., McAdams, A.C., Alkalaldeh, T. and Al-Saeed, M. (2005), "The Relationship Between Perceived Usefulness, Perceived Ease of Use, Perceived Information Quality, and Intention to Use E-Government", Journal of Theoretical and Applied Information Technology, pp. 30-44.

Anuwichanont, J. (2011), "The Impact of Price Perception on Customer Loyalty in The Airline Context", Journal of Business and Economics Research, Vol. 9 No. 9, pp. 37-50. Bock, G.W., Lee, J., Kuan, H.H. and Kim, J.H. (2012), "The Progression of Online Trust in The Multi-Channel Retailer Context and The Role of Product Uncertainty", Decision Support System, Vol. 53, pp. 97-107.

Chen, C.W.D. and Cheng, C.Y.J. (2009), "Understanding Consumer Intention in Online Shopping: A Respecification and Validation of the DeLone and McLean Model", Behavior and Information Technology, Vol. 28 No. 4, pp. 335-345.

Chen, J.V., Yen, D.C., Rajkumar, T.M. and Tomochko, N.A. (2011), “The Antecedents Factors on Trust and Commitment in Supply Chain Relationships", Computers Standards and Interfaces, Vol. 17 No. 2, pp. 139-155.

Chen, S.C., Yen, D.C. and Hwang, M.I. (2012), "Factors Influencing the Continuance Intention to The Usage of Web 2.0: an Empirical Study", Computers in Human Behaviour, Vol. 28, pp. 933-941.

Chen, Y.Y., Huang, H.L., Hsu, Y.C., Tseng, H.C. and Lee, Y.C. (2010), “Confirmation of Expectation and Satisfaction with the Internet Shopping: The Role of Internet Self Efficacy", Computer and Information Science, Vol. 3 No. 3, pp. 14-22.

Chiu, C.M., Huang, H.Y. and Yen, C.H. (2010), "Antecedents of Trust in Online Auction", Electronic Commerce Research and Application, Vol. 9, pp. 148-159.

Chu, C.W. and Lu, H.P. (2007), "Factors Influencing Online Music Purchase Intention in Taiwan", Internet Research, Vol. 17 No. 2, pp. 139-155.

Corbitt, B.J., Thanasankit, T. and Yi, H. (2003), "Trust and E-Commerce: A Study of Consumer Perception", Electronic Commerce Research and Application, Vol. 2, pp. 203-215.

Currall, S.C. and Judge, T.A. (1992), "Exploring the Trust Gap: Dimensions and Predictors of Trust among Labor and Management Representatives", Digital Commons, available at: www.digitalcommons.ilr.cornell.edu.

DeLone, W.H. and McLean, E.R. (2003), "The DeLone and McLean Model of Information System Success: A Ten Year Update”, Journal of Management Information System, Vol. 19 No. 4, pp. 9-30.

Ganguly, B., Dash, S.B., Cyr, D. and Head, M. (2010), "The Effects of Website Design on Purchase Intention in Online Shopping: The Mediating Role of Trust and the Moderating Role of Culture", International Journal of Electronic Business, Vol. 8 No. 4, pp. 302-330.

Gao, J., Zhang, C., Wang, K., and Ba, S. (2012), "Understanding Online Purchase Decision Making: The Effects if Unconscious Thought, Information Quality, and Information Quantity", available at: http://www.fdurop.fuand.edu.cn/upload/stu/docs/fUrStt_Understanding Online Purchase Decision Making-1299640443.pdf.

Gera, R. (2011), "Effects of Online Service Quality Dimension in Satisfaction, Value, and Behavioral Outcomes", International Journal of Arts and Science, Vol. 4 No. 12, pp. 123-140.

Ghane, S., Fathian, M. and Gholamian, M.R. (2011), "Full Relationship among E- 
Satisfaction, E-Trust, E-Service Quality, and E-Loyalty: The Case of Iran E-Banking", Journal of Theoretical and Applied Information Technology, Vol. 33 No. 1, pp. 1-6.

Grewal, D., Hardesty, D.M. and Iyer, G.R. (2004), "The Effects of buyer Identification and Purchase Timing on Consumer's Perception of Trust, Price Fairness, and Repurchase Intention", Journal of Interactive Marketing, Vol. 18 No. 4, pp. 87-100.

Halimi, A.B., Chavosh, A., Ghoshal, S.H., Salehi, M. and Pourabedin, Z. (2011), "The Influence of Perceived Service Quality on Relationships Marketing Orientations and Customer's Buying Behaviour in B2C Relationship from The Customer Perspective", International Conference on Economics and Finance Research, Vol. 4, pp. 208-212.

Hanif, M., Hafeez, S. and Riaz, A. (2010), "Factors Affecting Customer Satisfaction", International Research Journal of Finance and Economics, Vol. 60, pp. 44-52.

Hartono, J. (2007), Sistem Informasi Keperilakuan, Penerbit Andi, Yogyakarta.

Hartono, J. and Abdillah, W. (2009), Konsep and Aplikasi PLS (Partial Least Square) Untuk Penelitian Empiris, 1st ed., BPFE, Yogyakarta.

Hermann, A., Xia, L., Monroe, K.B. and Huber, F. (2007), "he Influence of Price Fairness on Customer Satisfaction: An Empirical Test in the Context of Automobile Purchase", Journal of Product and Brand Management, Vol. 16 No. 1, pp. 49-58.

Hitosugi, C. (2011), "Trust on The Web: The Power of Subjective Norm across Cultures", available

at: http://claireh.weebly.com/uploads/5/2/9/9/5299882/hitosugi_sninonlinetrust_c rosscultureconf_dec2011.pdf.

Hsieh, C.C., Kuo, P.L., Yang, S.C. and Lin, S.H. (2010), “Assessing Blog User Satisfaction using The Expectation and Disconfirmation Approach", Computers in Human Behaviour, Vol. 26, pp. 1434-1444.

Hsu, H.Y. and Tsou, H.T. (2011), "The Effect of Website Quality on the Consumer Emotional States and Repurchase Intention", African Journal of Business Management, Vol. 5 No. 15, pp. 6195-6200.

Hsu, M.H. and Chiu, C.M. (2004), "Predicting Electronic Service Continuance with A Decomposed Theory of Planned Behaviour", Behaviour and Information Technology, Vol. 23 No. 5, pp. 359-373.

Hwang, Y. and Kim, D.J. (2007), “Customer Self Service System: The Effects of Perceived Web Quality with Service Contents on Enjoyment, Anxiety, and E-Trust”, Decision Support System, Vol. 43, pp. 746-760.

Jeffries, F.L. and Becker, T.E. (2008), "Trust, Norms, and Cooperation: Development and Test of a simplified model", JBAM, Vol. 9 No. 3, available at: http://www.ibam.com/pubs/jbam/articles/vol9/no3/JBAM_9_3_5.pdf.

Jiang, P. and Rosenbloom, B. (2005), "Customer Intention to Return Online: Price Perception, Attribute Level Performance, and Satisfaction Unfolding Over Time", European Journal of Marketing, Vol. 39 No. 1, pp. 150-174.

Kettinger, W.J., Park, S.H. and Smith, J. (2009), "Understanding The Consequences on Information System Service Quality in IS Service Reuse", Information and Management, Vol. 46, pp. 335-341.

Kim, J., Hong, S., Min, J. and Lee, H. (2011), "Antecedents of Application Service Continuance: a Synthesis of Satisfaction and Trust", Expert System with Applications, Vol. 38, pp. 9530-9542.

Kuan, H.H., Bock, G.W. and Vathanophas, V. (2008), "Comparing the Effects of Website Quality on Customer Initial Purchase and Contained Purchase at E-Commerce Websites", Behaviour and Information Technology, Vol. 27 No. 1, pp. 3-16.

Kuo, Y.F., Wu, C.M. and Deng, W.J. (2009), “The Relationships among Service Quality, 
Perceived Value, Customer Satisfaction, and Post Purchase Intention in Mobile Value Added Services", Computers in Human Behaviour, Vol. 25, pp. 887-896.

Lee, K.C. and Chung, N. (2009), "Understanding Factors Affecting Trust and Satisfaction with Mobile Banking in Korea: a Modified DeLone and McLean's Model Perspective", Interacting with Computers, Vol. 21, pp. 385-392.

Lee, K.C., Kang, I. and Kim, J.S. (2007), "Exploring The User Interface of Negotiation Support System from The User Acceptance Perspective”, Computers in Human Behaviour, Vol. 23, pp. 220-239.

Li, X., Hess, T.J. and Valacich, J.S. (2008), "Why do We Trust New Technology? A Study of Initial Trust Formation with Organizational Informational System", Journal of Strategic Information System, Vol. 17, pp. 39-71.

Liao, C., Chen, J.L. and Yen, D.C. (2007), "Theory of Planning Behaviour and Customer Satisfaction in The Continued Use of E-Service: an Integrated Model", Computers in Human Behaviour, Vol. 23, pp. 2804-2822.

Liao, C., Liu, C.C., Liu, Y.P., To, P.L. and Lin, H.L. (2011), "Applying the Expectancy Disconfirmation and Regret Theories to Online Consumer Behavior", Cyberpsychology, Behavior, and Social Networks, Vol. 14 No. 4, pp. 241-246.

Liao, C.H., Tsou, C.W. and Shu, Y.C. (2008), "The Roles of Perceived Enjoyment and Price Perception in Determining Acceptance of Multimedia - on - Demand", International Journal of Business and Information, Vol. 3 No. 1, pp. 27-52.

Lin, C.C., Wu, H.Y. and Chang, Y.F. (2011), "The Critical Factors Impact on Online Customer Satisfaction", Procedia Computer Science, Vol. 3, pp. 276-281.

Lin, C.Y., Fang, K. and Tu, C.C. (2010), "Predicting Consumer Repurchase Intentions to Shop Online”, Journal of Computers, Vol. 5 No. 10, pp. 1527-1533.

Lodorfos, G.N., Mulvana, K.L. and Temperley, J. (2006), “Consumer Behaviour: Experience, Price, Trust, and Subjective Norms in The OTC Pharmaceutical Market", Innovative Marketing, Vol. 2 No. 3, pp. 41-66.

Mao, D. (2010), "A Study of Consumer Trust in Internet Shopping and The Moderating Effect on Risk Aversion in Mainland China".

McGill, T. and Klobas, J. (2008), "User Developed Application Success: Sources and Effect of Involvement", Behaviour and Information Technology, Vol. 27 No. 5, pp. 407-422.

Munusamy, J., Chelliah, S. and Pandian, S. (2011), "Customer Satisfaction Delivery in Airline Industry in Malaysia: a Case of Low-Cost Carrier", Australian Journal of Basic and Applied Sciences, Vol. 5 No. 11, pp. 718-723.

Neuman, W.L. (2000), Social Research Methods, 4th ed., Allyn and Bacon, Massachusets.

Nicolaou, A.I. and McKnight, D.H. (2006), "Perceived Information Quality in Data Exchanges: Effect on Risk, Trust, and Intention to Use".

Ou, C.X. and Sia, C.L. (2010), "Consumer Trust and Distrust: an Issue of Website Design", International Journal of Human-Computer Studies, Vol. 68, pp. 913-934.

Palmer, J.W. (2002), "Website Usability, Design, and Performance Metrics”, Information System Research, Vol. 13 No. 2, pp. 151-167.

Park, J.S., Kim, J.J. and Koh, J. (2010), “Determinants of Continuous Usage Intention in Web Analytics Service”, Electronic Commerce Research and Applications, Vol. 9, pp. 61-72.

Pavlou, P.A. and Gefen, D. (2004), "Building Effective Online Marketplaces with Institution-Based Trust", Information System Research, Vol. 15 No. 1, pp. 37-59.

Rai, A., Lang, S.A. and Welker, R.B. (2002), "Assessing the Validity of IS Success Model: An Empirical Test and Theoretical Analysis", Information System Research, Vol. 13 No. 1, pp. 50-69.

Ramayah, T., Rouibah, K., Gopi, M. and Rangel, G.J. (2009), “A Decomposed Theory of 
Reasoned Action to Explain Intention to Use Internet Stock Trading among Malaysian Investors", Computers in Human Behaviour, Vol. 25, pp. 1222-1230.

Roca, J.C., Chiu, C.M. and Martinez, F.J. (2006), “Understanding E-Learning Continuance Intention: an Extension of The Technology Acceptance Model”, International Journal of Human-Computer Studies, Vol. 64, pp. 683-696.

Tsai, H.T. and Huang, H.C. (2007), "Determinant of E - Repurchase Intentions: An Integrative Model of Quadruple Retention Drivers", Information and Management, Vol. 44, pp. 231-239.

Wang, C.C., Chen, C.A. and Jiang, J.C. (2009), "The Impact of Knowledge and Trust on E Consumer's Online shopping Activities: An Empirical Study", Journal of Computers, Vol. 4 No. 1, pp. 11-17.

Wijayanti. (2012), Pengaruh Kegunaan Persepsian, Kemudahan Penggunaan Persepsian, Norma Subyektif, and Resiko Persepsian Terhadap Penggunaan Aktual Aplikasi Paperless Office Di Universitas Gadjah Mada.

Yang, H.E., Wu, C.C. and Wang, K.C. (2009), "An Empirical Analysis of Online Games Service Satisfaction and Loyalty", Expert System with Application, Vol. 36, pp. 18161825.

Yulihasri., Islam, M.A. and Daud, K.A.K. (2011), “Factors that Influence Customer's Buying Intention on Shopping Online", International Journal of Marketing Studies, Vol. 3 No. 1, pp. 128-139.

Zeng, F., Hu, Z., Chen, R. and Yang, Z. (2009), “Determinants of Online Service Satisfaction and Their Impacts on Behavioural Intentions", Total Quality Management, Vol. 20 No. 9, pp. 953-969.

Zhang, X. and Feng, Y. (2009), The Impact of Customer Relationship: Marketing Tactics on Customer Loyalty, available at: www.diva-portal.org.

Zhang, Y., Fang, Y., Wei, K.K., Ramsey, E., McCole, P. and Chen, H. (2011), "Repurchase Intention in B2C E-Commerce, A Relationship Quality Perspective", Information and Management, Vol. 48, pp. 192-200.

Zhou, T. (2012), “Understanding User's Initial Trust in Mobile Banking: an Elaboration Likelihood Perspective", Computer in Human Behaviour, Vol. 28, pp. 1518-1525. 